\title{
DE FAMILIE VAN HEEMSKERK IN SURINAME
}

DOOR

FRED. OUDSCHANS DENTZ

Mr. Jean Henry, graaf van Heemskerk, Heer van Achtienhoven en Schepen van de stad Haarlem, was op 18 Maart 1763 gehuwd met Geertruid Catharina Testart, dochter van Elbert en van Anna Margaretha Fannius. Hij vertrok met zijn gezin naar Suriname en voerde daar de administratie over zeer veel plantages. Tijdens zijn verblijf in Suriname overleed zijn echtgenoote op 21 Sept. 1775. Zij werd in den Nieuwen Oranjetuin te Paramaribo begraven, waar een zerk haar graf dekt met de wapens van Testart, Fannius van Oud-Haerlem, Slicher en Guldenwagen. Het opschrift luidt:

GEERTRUID CATARINA TESTART

GEBOREN DEN 7 DECEMBER 1743

OVERLEDEN DEN 21 SEPTEMBER 1775

Van Heemskerk hertrouwde op 8 Augustus 1778 met Johanna, Suzanna Francina Dandiran, dochter van David Theodoor Dandiran, Raad van Politie en Johanna Catharina des Loges.

Hun eenigst dochtertje kwam in 1788 op den leeftijd van 5 jaren te overlijden en naast het graf van Van Heemskerks eerste vrouw werd het ter aarde besteld, waar op haar grafzerk gebeiteld staat

$$
\begin{aligned}
& \text { F. M. VAN HEEMSKERK } \\
& \text { GESTORVEN DEN } 24 \\
& \text { JANUARI } 1788 \text { OUD VYF JAREN. }
\end{aligned}
$$

Vier jaar later keerde Van Heemskerk naar Europa terug en vestigde zich in Frankrijk.

Om de betrekkingen van Van Heemskerk met andere patriciërsfamilies aan te duiden kan worden vermeld, dat zijn eerste vrouw de dochter was van Elbert Testart, Schepen, Raad en Burgemeester van Haarlem, Raad ter Admiraliteit en Bewindhebber van de O.I. Comp., wiens moeder Geertruida Slicher heette, die 
een zuster was van Catharina Elisabeth Slicher, de moeder van gouverneur Wigbold Crommelin.

De broeder van zijn schoonvader, Mr. Pierre Cypriaan Testart, was Secretaris van Amsterdam, bewindhebber der W.I. Comp., die met Agatha Hieronima Nobel gehuwd was. Hun dochter huwde op 2 Juni 1771 met Mr. Quiryn Willem van Hoorn, Heer van Noordwykerhout, Schepen en Burgemeester van Amsterdam.

Op het tweede huwelijk van Jan Hendrik van Heemskerk met jonkvrouw Johanna Dandiran vervaardigde de dichter P. F. Roos een gedicht, op blz. 123 van zijn Eerstelingen van Surinaamsche Mengelpoëzie (1783) terug te vinden.

Plantage „Misgunst” in Suriname droeg den Negerengelschen naam „Heemskerki”. 